\title{
Athenian 'Imperialism' in the Aegean Sea IN THE 4TH Century BCE: The Case of Keos*
}

\author{
Wojciech Duszyński \\ iD http:/orcid.org/0000-0002-9939-039X \\ Jagiellonian University in Kraków
}

\begin{abstract}
This article concerns the degree of direct involvement in the Athenian foreign policy in the 4th century BC. One of main questions debated by scholars is whether the Second Athenian Sea League was gradually evolving into an arche, to eventually resemble the league of the previous century. The following text contributes to the scholarly debate through a case study of relations between Athens and poleis on the island of Keos in 360s. Despite its small size, Keos included four settlements having the status of polis: Karthaia, Poiessa, Koresia and Ioulis, all members of the Second Athenian League. Around year 363/2 (according to the Attic calendar), anti-Athenian riots, usually described as revolts, erupted on Keos, to be quickly quelled by the strategos Chabrias. It is commonly assumed that the Athenians used the uprising to interfere directly in internal affairs on the island, enforcing the dissolution of the local federation of poleis. However, my analysis of selected sources suggests that such an interpretation cannot be readily defended: in fact, the federation on Keos could have broken up earlier, possibly without any external intervention. In result, it appears that the Athenians did not interfere in the local affairs to such a degree as it is often accepted.
\end{abstract}

Keywords: Athens, Keos, Koresia, Karthaia, Poiessa, Ioulis, Aegean, 4th century BC, Second Athenian League, Imperialism.

According to the most classical vision of Greek history, the 4th century BCE was a period when Athens made several attempts to regain the glory and power it had achieved in the previous century; tellingly, E. Badian even coined the term, 'the ghost of Empire,' to express the extent to which the Athenians were infatuated with their great past. ${ }^{1}$ This Athenian drive to regain lost excellence mainly focused on rebuilding their arche in the

${ }^{*}$ The present paper was prepared thanks to the grant from the National Science Centre: UMO-2012/7/B/ HS3/03455.

1 Badian 1995, 79-81. Rhodes (2012, 117-127) takes a much more cautious view: the 'new' Athenian imperialism had become evident only after the battle of Leuctra in 371. 
Aegean Sea; nevertheless, the local political, social and economic conditions in the region did not favour the Athenian efforts, many of their successive initiatives eventually proving futile. ${ }^{2}$ Notably, the Athenians did not learn from their failures and did not as a community acknowledge that what worked in the fifth century could not work in the fourth: locked in a vicious circle of repeating old mistakes, they finally had to yield to the rising Macedonian power. A particularly clear manifestation of their overreaching aspirations was supposedly the development of the Second Athenian League (ca. 378). Officially, the confederation meant to protect the autonomy of the member states against Spartan designs, with checks and balances introduced to prevent the alliance from turning into an Athenian empire: for example, the Athenians could neither own land in the federated poleis nor participate in sessions of the synedrion, a decision-making body made up of their allies. ${ }^{3}$ Despite such precautions, Athens allegedly found ways to abuse the bylaws and soon began to interfere in the internal matters of the individual states.

The scholarly consensus presented above, although still widespread today, has been criticised by some contemporary historians, who have pointed out that several sweeping simplifications must be made to accept this version of events. Granted, the Athenians must have longed to rebuild their old arche, but the ways and means they used toward that goal were not straightforward. Significantly, J. Cargill concluded in his monograph on the Second Athenian League that almost all attested Athenian actions that aimed at subjugating specific states (such as Samos in 366) involved poleis not included in the symmachia ${ }^{4}$ therefore, we can hardly accuse the Athenians of violating their obligations towards their allies. Cargill's conclusions have not been readily and universally accepted by historians, with a subset of scholars having pointed out several cases of controversial Athenian behaviour towards their allies. ${ }^{5}$ A case in point (crucial to this analysis mainly due to the sheer amount of surviving source material) is the Athenian intervention in the internal affairs of the island of Keos, whose cities belonged to the Second Athenian League in the 360 s.

Keos (present-day Kea) lies fairly close to the south-eastern coast of Attica, long included in the archipelago of Cyclades. ${ }^{6}$ Despite its small size $\left(159 \mathrm{~km}^{2}\right)$, the island hosted no less than four settlements described as poleis: Karthaia, Poiessa, Koresia and Ioulis. ${ }^{7}$ Due to its high concentration of urban centres, Keos constitutes a remarkable outlier among the Aegean islands, but it has so far only rarely attracted the scholarly attention it rightly deserves. ${ }^{8}$ At the very beginning of the 4 th century, the island remained under the Spartan influence; Demosthenes mentions that a Lacedaemonian harmost held an office on Keos prior to the outbreak of the Corinthian War in 395. ${ }^{9}$ During

2 E.g. Beloch 1922, 93-95, 195-196, 237-238; Cloche 1934, 307-336; Perlman 1968; Cawkwell 1981, 47; Buckler 2003, 377-379.

3 Marshall 1905, 16-20; Accame 1941, 53-59; Cargill 1981, 131-134, 146-148; Badian 1995, 91.

4 Cargill 1981. For a traditional and opposing view, see Cloche 1934, 157-158; Davies 1969, 331-333; Bonnin 2015, 266.

5 E.g. Hornblower 1982; Martin 1984.

6 Strabo 10.5.3 (485C); Bürchner 1921, 182-183.

7 Strabo 10.5.6 (486C); Pliny, NH 4.12.64; Ps-Scylax 58.

8 It is worth noting that A. Pridik's work (1892) remains the only comprehensive monograph on ancient Keos.

9 Dem. 18.96. 
this conflict, the harmost was probably removed from the island as a result of Conon's actions following the Battle of Cnidus in $394 .{ }^{10}$ The island then disappeared from the pages of history until 376, when the Spartan fleet reportedly operated near it prior to the Battle of Naxos. ${ }^{11}$ It was also around that time that the local poleis on Keos joined the Second Athenian League.

In the 360s (363/2 or the previous one, according to the Attic calendar), the poleis on Keos rioted against Athens, with the disturbance usually being described as a revolt. Some historians suspect the riots started due to a Theban interference, ${ }^{12}$ because the unrest concurred with Epaminondas' sea expedition as described by Diodorus of Sicily (364); the Theban allegedly encouraged his compatriots to attempt to challenge the Athenian domination over the Aegean Sea. ${ }^{13}$ The fleet he built set sail and achieved some short-term successes $;{ }^{14}$ one of them reportedly being the revolt on Keos, although Diodorus never mentions whether the Thebans landed there.

Our knowledge on the events on Keos comes from a number of local inscriptions, forming the largest database of information related to the island's history in the Classical period. The said inscriptions reveal that riots have intermittently started on the island in the analysed period, to be quelled by the strategos Chabrias, a renowned military commander. The historians commonly accept that, as a part of punitive measures against Keos, the Athenians considerably increased their interference in the internal affairs on the island. Reportedly, the local poleis joined to create a federation (koinon), its origin dated by historians to the 360 s, the early 3 rd century, or even to the preceding century. ${ }^{15}$ After the riots, the union of the islanders was allegedly abolished. ${ }^{16}$ In the eyes of many, the events of $363 / 2$ on Keos constitute a clear example of imperialist aspirations of the hegemon of the League, with the Athenians more than willing to brutally suppress the autonomy of the League's individual members. Furthermore, many historians argue that the 360s marked the time when the Athenians, inspired by exploitative practices of the former Delian League, began to treat their allies in a harsh and condescending manner, which, among other causes, led to the subsequent outbreak of the War of the

10 Xen. Hell. 4.8.1. After the victory at Cnidus, Conon started to remove Spartan garrisons from individual cities in the Aegean. We know that he visited Athens (Hell. 4.8-10). Therefore, it is more than likely that he took care to remove the Spartan garrison from Keos (see Thomopoulos 1954, 321).

11 Xen. Hell. 5.4.31.

12 Pridik 1892, 37; Bürchner 1921, 189; Beloch 1922, 197; Ruzicka 1998, 62, note 11; Buckler 2003, 365; Rhodes - Osborne 2003, no. 39, commentary, 201; Bonnin 2015, 268.

13 Diod. 15.79.1.

14 Ruzicka (1998) believes that Epaminondas' fleet achieved a degree of success, fomenting rebellions among some Athenian allies (Byzantium, Chios and Rhodes), which were never completely suppressed and continued to smoulder until the outbreak of the War of the Allies (357); however, many scholars hold a contrary opinion, cf. e.g. Cawkwell 1981, 270-273; Stylianou 1998, 494-497; Buckler 2003, 365-366.

15 For the issue of the definition of the koinon as a unified state (which is sometimes referred to as the federal state in English or the Bundesstaat in German), see Beck 1997, 11-13 and 18-19. For its creation on Keos, see Pridik 1892, 31-32 (5th century); Lewis 1962, 2-3 (dating its creation to the end of the 5th century); Swoboda 1923, 46 (dating its creation to the time not long before the revolt of 363/2); Brun 1989, 130-134 (dating its creation to a period from the beginning of the 4th century).

16 Swoboda 1923, 48-49; Thomopoulos 1954, 319-321; Lewis 1962; Brun 1989, 128-131; Dreher 1989, 267-272; Reger 2004, 748; Cooper 2008, 37. Then again, Pridik (1892, 35-36) believes that the federal state was abolished earlier, after Keos had joined the Second Athenian League. 
Allies. ${ }^{17}$ The main interpretative problem concerns the shortage of material attesting to the quotidian functioning of the alleged federal state on the island. Similarly, we lack information indicating that the federation was abolished by the Athenians.

To consider the internal structure of the federation on Keos, one must first appraise whether the term Keĩos/Keĩor (Keios/Keioi) has indeed denoted a political community, which is usually the case with Greek ethnonym. In the Greek literature, references to the Keioi appear in e.g. Bacchylides (the Kean resident), Pindar, and Herodotus. ${ }^{18}$ The author of the Histories mentions that ships from the island fought against the Persians at Artemisium and Salamina. ${ }^{19}$ In the 5th century, the poleis on Keos belonged to the Delian League, probably remaining its part until the League's dissolution. On tribute lists, the citizens of Keos appear both under their individual names and under the collective term, Keioi. ${ }^{20}$ Drawing on abovementioned data, K. Buraselis makes a case that the local poleis engaged in some form of political collaboration but were not necessarily unified (since each struck their own coinage). ${ }^{21}$ In the 4th century, the collective ethnicon Keioi appears repeatedly in the epigraphic material. In the famous inscription of the Decree of Aristoteles, all the poleis from Keos are listed among member states of the Second Athenian League, but in a rather peculiar form. The first to appear is Poiessa, recorded in separation from neighbouring polities, ${ }^{22}$ the remaining three appear much later under the collective term Kcí $\omega v$, with their individual names appended as well. ${ }^{23}$ The ordering implies that Poiessa, an autonomous city-state, joined the Athenian League independently of its neighbouring poleis and probably before other ones $\mathrm{did} .{ }^{24}$ As for remaining cities, the reasons behind this arrangement and grouping remain unclear. Many historians claimed that grouping them together may suggest that they formed a separate political union which did not include Poiessa. ${ }^{25}$ Nonetheless, an alternative interpretation exists for their rendering in the decree text through the genitive Keí $\omega v$ : if understood as a common genetivus partitivus ('from among the citizens of Keos'), the ethnicon would in principle refer only to the territory on which the cities were situated. Such an interpretation of the genitive is corroborated by an analogous case from Kefallenia: the charter of the Second Athenian League includes one of its cities, Pronnoi, recorded under the collective term

17 Marshall 1905, 78-81, 91-93; Beloch 1922, 237; Accame 1941, 181.

18 Pind. Isthm. 1.9; Bacch. Epin. 6.5; Epigr. 1.4; Hdt. 8.1.2; 8.46. 2; 8.76.1.

19 Hdt. 8.1.46, 9.81.

20 Meritt - Wade-Gery - MacGregor 1950, no. 198-199; IG I3 262, 263, 270, 289; see Pridik 1892, $30-31$.

21 Buraselis 2015, 366-367.

$22 I G \mathrm{II}^{2} 43, l .82$.

23 IG $\mathrm{II}^{2} 43, l l .120-122$.

24 It is often accepted that Poiessa joined the Second Athenian League earlier than the remaining cities. Chronologically, its accession is dated to before the Battle of Naxos. It is usually linked to Chabrias' activity in the summer of 377, when he reportedly befriended Peparethos, Skiathos and a few Cycladic islands on behalf of Athens (Diod. 15.30.5). The remaining cities supposedly did not join the symmachia until after the Battle of Naxos (376), see Marshall 1905, 59; Accame 1941, 78, 81; Brun 1989, 134. However, there is no complete consensus on the matter among historians. Pridik $(1892,35)$ believes that Poiessa joined the league in 376 and the other poleis in 375 . Cargill $(1981,34,38)$ is of the opinion that there are no grounds for dating Poiessa joining the Second Athenian League. He is inclined to date the membership of the other cities to 376/375. Buckler $(2003,249)$, on the other hand, maintains that all the cities joined after the Battle of Naxos.

25 Lewis 1962, 2; Brun 2004, 74; Buraselis 2015, 278; Bonnin 2015, 266. 


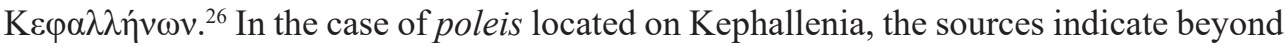
much doubt that the poleis at the time did not form any political unions. ${ }^{27}$ By analogy, the use of the ethnicon Keioi by itself does not necessarily has to point to an existence of a specific and separate political community on the island. ${ }^{28}$ This pivotal conclusion influences our interpretation of the remaining material: a slightly later inscription, dated to $374 / 3$, mentions the Keioi as debtors of the Delian sanctuary. ${ }^{29}$ In other words, the islanders on Keos could have lived together in an amphictyony, known as one ethnos, but not necessarily did they form a political union.

The Decree of Aristoteles is rather indicative of the autonomy of the individual poleis on Keos. We can also observe that, in the face of the ambiguity of the term Keioi, it is necessary to search for other information on how the community on Keos functioned as a state. Of fundamental importance in this context are the pair of inscriptions recording treaties between Keos and, respectively, Histiaea and (possibly) Eretria. ${ }^{30}$ Both inscriptions record isopoliteia (equal citizenship) agreements, supposedly signed between Keos as a unit and two abovementioned cities, and describe how to allocate land to a citizen of one state who wants to settle in another. On Keos, the allocation was the responsibility of the nomophylakes. The texts also state that the island had a uniform administrative structure, with all poleis dividing into phylai, trittyes and khoroi. ${ }^{31}$ In sum, the use of the ethnicon Keioi in these texts denotes that the island acted as a unified political body. Nevertheless, the described pair of inscriptions constitutes the singular surviving source material which strongly supports the interpretation that poleis of Keos acted as a federate state. Challengingly, their texts cannot be securely dated to any decade, with historians broadly ascribing them to the 4 th century. As a result, we cannot definitively conclude on the basis of these two treaties that a federation of any type existed on Keos in the 360s.

Let us now turn our attention to the most informative extant description of the unrest on the island, contained in a well-preserved Athenian inscription that details many particulars about the history of Keos in the 4th century. The inscription's undamaged beginning, including the name of the archon-eponym, securely dates the text to the Attic year 363/2. The first issue dealt with in the text concerns financial settlements: the city of Ioulis has to pay off its debt to the Athenians. ${ }^{32}$ Subsequently, the inscription refers to the agreements which the Athenian strategos Chabrias signed with the islanders, both on behalf of his own polis and on behalf of those inhabitants of Keos whom the Athenians brought back..$^{33}$ The text specifies that cities of Ioulis and Karthaia have erected stone steles with the treaty provisions, with names of two other cities missing. ${ }^{34}$ Further on, the inscription narrates the events occurring during the next stage of the unrest on the island, apparently sparked off by people of Ioulis alone, with other islanders not

${ }^{26} I G I^{2} 43, l l .107-108$.

27 Gehrke - Wierbelauer 2004, 369-371.

28 Reger 1996, 474-477.

${ }^{29} I G \mathrm{II}^{2} 1635, l l .12,111$.

$30 \quad I G$ XII 5.594; BCH 78 (1954), 316-318 = SEG 14.530. The identification of Eretria is uncertain, since the toponym occurs in a passage that has been damaged.

31 IG XII 5.594, l. 6; SEG 14.530, l. 8.

${ }_{32} I G \mathrm{II}^{2} 111, l l .4-17$.

$33 I G \mathrm{II}^{2} 111, l l .17-19$.

${ }^{34} I G \mathrm{II}^{2} 111, l l .20-25$. 
mentioned in the text. Ioulis supposedly violated the terms of Chabrias' agreement and fought against the Athenians, the inhabitants of Keos, and other allies. ${ }^{35}$ The subsequent part of the inscription relays further developments during the unrest: those sentenced to death as a result of the earlier events return to the island; the stele with the text of the treaty signed by Chabrias is destroyed; supporters of Athens are killed and their property is confiscated. ${ }^{36}$ The depicted chain of events corresponds rather closely with a typical scenario of a city stasis. The text also mentions that the rioting poleis killed the Athenian proxenos, most probably during the earlier stage of the riots. ${ }^{37}$ The punishment Athens inflicted on individual poleis after the riots was not excessively severe: the text of the inscription speaks of a number of people being exiled and their property being confiscated. Furthermore, exiles (if they considered themselves unjustly convicted) retained the right to appeal their banishment in courts on Keos and in Athens. ${ }^{38}$ The terms of the treaty also included measures aimed at fostering reconciliation among the inhabitants of the island, and, with regard to external affairs, a guarantee of Keos' loyalty towards the Athenians and their allies. ${ }^{39}$ Finally, the inscription mentions the issue of court appeals in cases against the Athenians. ${ }^{40}$

The informative inscription discussed above reveals much about the unrest on the island, but it does not specify its causes, scale, or external context. Expressly, we know little about the earlier riots in Ioulis and Karthaia, suppressed by Chabrias. ${ }^{41}$ The reference to islanders returning to Keos indicates that the riots probably took the form of stasis, with the Athenians involved only as peripheral actors. Whether the revolt spread across the entire island remains uncertain: the source testifies only to the involvement of Ioulis and Karthaia. The later revolt (recast by our source as a war through the use of the verb $\pi \mathrm{o} \lambda \varepsilon \mu \varepsilon \dot{\varepsilon}()$ was probably restricted to Ioulis. Consequently, different groups of islanders must have held very different opinions about the smouldering rebellion, with cities either joining the rebels' cause or supporting the Athenians. In the case of Ioulis' second revolt, the text specifies that the rioting polis also fought against other inhabitants of Keos, whereas the city of Karthaia won the Athenians' praise for supporting their cause. ${ }^{42}$ Eventually, pledges of goodwill were exchanged between the Athenians and the Keioi, suggesting that the island's poleis, at least at this point in time, acted as a collective. Therefore, in light of the discussed inscription, it appears that the island in the Attic year 363/2 probably was not a united political organism that pursued a common policy.

All in all, one should not admit the riots described in $I G \mathrm{II}^{2} 111$ as evidence for the existence of a federal state on Keos, since the said federation, described only in the pair of abovementioned treaties existed, could have existed at any given time in the 4 th century. Consequently, we can hardly assume that the alleged federation was abolished by

$35 I G \mathrm{II}^{2} 111, l l .27-30$.

36 IG $\mathrm{II}^{2} 111$, ll. 30-36.

$37 I G \mathrm{II}^{2} 111$, ll. 38-40.

$38 I G \mathrm{II}^{2} 111, l l .41-49$.

$39 I G \mathrm{II}^{2} 111, l l .41-49$.

40 IG $\mathrm{II}^{2} 111$, ll. 74-75.

41 W. Laqueur $(1927,179-183)$ believes that Chabrias suppressed the later revolt that erupted in Ioulis only. However, his is an outlying and, it seems, frequently refuted opinion (see Cooper 2008, 35-36).

42 IG $\mathrm{II}^{2} 111, l .54$. 
the Athenians as a punishment after the rebellion of 363/2. As I specified above, the research on this matter suffers from a dearth of sources: only one other Athenian epigraphic source, unfortunately surviving in fragments, can shed some light on the relations between Athens and Keos in the examined period. The fragmentary text in question refers to an earlier treaty between Chabrias and the islanders, of uncertain relation to the revolt: it notes that the inhabitants of Keos should be governed by cities ( $\pi \circ \lambda 1 \tau \varepsilon v \varepsilon \varepsilon \sigma \theta \alpha 1$

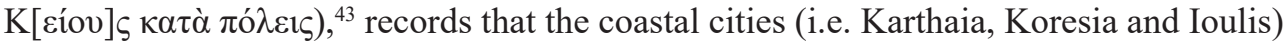
were to repair their fortifications, and stipulates that any court disputes about customs duties ( $\pi \varepsilon v \tau \eta \kappa о \sigma \tau \eta)$ should be adjudicated by Athenian courts. ${ }^{44}$ The passage about being governed by cities is frequently interpreted as evidence for the post-rebellion abolishment of Keos' federal state. ${ }^{45}$ Due to the fragmentary and damaged nature of this testimony, one cannot convincingly argue for or against the matter at hand, but it does appear that the islanders at least considered, if not established, some forms of regional political organisation.

Unfortunately, as the header of the Athenian inscription in question has not survived, we cannot date it with any precision, with our approximate estimate ascribing it to the period between 363 and 355 . Some historians regard the inscription as recording the original treaty that ended the first period of unrest on the island, or perhaps its revision or an addendum, since Chabrias the strategos, the signatory of this treaty, also suppressed the first revolt. ${ }^{46}$ Other scholars date the inscription to the Social War. ${ }^{47}$ The very manner in which the text refers to an earlier treaty indicates that some time elapsed before it was issued. Furthermore, the inscription clearly speaks of an agreement made

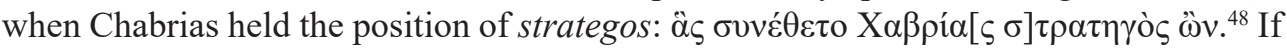
the matter had been current, it would have sufficed to use the standard formula: X $\alpha \beta p i ́ \alpha \varsigma$ o $\sigma \tau \rho \alpha \tau \eta \gamma$ ós, which appears in $I G \mathrm{II}^{2} 111$; therefore, it seems that the analysed inscription should be dated to sometime after the events of 363/2. It is impossible to establish whether the context of the Social War was current on the day when the treaty was concluded. Supporters of this interpretation mainly draw parallels between this formula and the single inscription from Andros concerning an Athenian garrison stationed there during the conflict between the allies. Nevertheless, the parallels between two texts cannot constitute sufficient evidence to support such an interpretation, especially if we consider that the damaged comparandum was subject to contemporary emendations. ${ }^{49}$

The sources presented here so far do not enable historians to propose definitive conclusions. The discussed treaties concerning an isopoliteia stand for the only testimony that directly mentions the existence of a federal state on Keos. The brevity of their texts does not invite confidence and indicates that a political union on the island, if ever extant,

$43 I G \mathrm{II}^{2} 404, l l .12-13$.

$44 I G \mathrm{II}^{2} 404$, ll. 15-18.

45 Lewis 1962, 4; Dreher 1989, 265, 268; Brun 1989, 123-124; Brun 2004, 74.

46 Maier 1959, 158-159; Ruschenbusch 1982, 181; Dreher 1989, 267-269; Cooper 2008, 38-40.

47 Schweigert 1939, 14, note 2; Lewis 1962, 4; Brun 1989, 123; Brun 2004, 76-77; Bonnin 2015, $276-277$.

$48 I G \mathrm{II}^{2} 404, l .12$

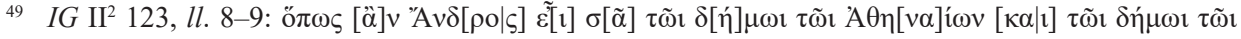
Av $\delta \rho i ́ \omega v$. 
did not survive for long. If it had existed for a longer period of time, it should have left a body of evidence: further inscriptions or mentions by ancient writers. It is also highly unlikely that the state covered the entire territory of Keos. The three-way division into trittyes does not match an island with four political centres; since Poiessa consistently appears apart from other island poleis in the surviving sources, it probably did not belong to their federal state. ${ }^{50}$ Additionally, the imprecise dating of the pair of treaties mentioning the questionable isopoliteia (the 4th or even late 5th century) hinders attempts at linking them to the period discussed in this article. ${ }^{51}$ Consequently, the scant and inconclusive documentary evidence does little to outline the putative development of a federal state on Keos. The substantial majority of the available material attests to the autonomy of the cities on the island both before (the Decree of Aristoteles) and during the revolts ( $I G \mathrm{II}^{2} 111$ ), with those linking the putative establishment of an island federation to the revolt of 363 doing so on very shaky grounds of territorial and temporal concurrence. The only point in favour of this link comes from $I G \mathrm{II}^{2} 404$ that specifies that the cities on Keos have been divided (regarded as evidence for the existence of a federal state and its subsequent abolishment) and mentions Chabrias, the general who suppressed the revolt. Still, the text of this inscription appears to postdate the issue of the $I G \mathrm{II}^{2} 111$ analysed above, from which it clearly follows that the island's cities pursued autonomous policies.

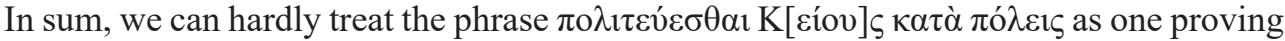
that the islanders' federation had been abolished.

Fresh evidence concerning the political makeup of the island may be found in an inscription cataloguing inhabitants of Ioulis. Dated to the late 4th century, the inscription most likely names citizens obliged to military service, dividing them by territorial units. One of the specified groups within Ioulis, the Koresioi, share their name with inhabitants of one of the island's poleis. ${ }^{52}$ Some historians believe that this equivalence reflects Koresia's synoikism with Ioulis; nonetheless, such a union did not occur until the Hellenistic period, with Koresia recorded in inscription on its own until as late as the 3rd century. ${ }^{53}$ In light of this, one would need to claim that Ioulis and Koresia merged at least twice, once briefly in the 4th century and then lastingly in the Hellenistic period, but remained independent poleis in the interval, as reflected by their political separation in other documents from that period. On the grounds of onomastic and prosopographic linkages (some names reappear in $I G \mathrm{II}^{2} 111$ and $\left.\mathrm{II}^{2} 404\right)$, P. Brun provisionally connects the presence of the Koresioi in Ioulis to the upheaval of the late 360s, although he hesitates to draw conclusions concerning the island's unification. ${ }^{54}$ E. Ruschenbusch concludes similarly that, in his opinion, the cities unified at that time against the threat of piracy (including activities of Alexander of Pherai). ${ }^{55}$ Another group of historians challenges interpretations that cast the appearance of the Koresioi in the inscription as evidence for some type of federation of the poleis at that time; they argue that the text may simply reflect some form of military cooperation, or perhaps pooling of human capital for a joint en-

50 Lewis 1962, 2.

51 Thomopoulos 1954, 320-321.

52 IG XII 5.609, l. 175.

53 Robert 1960, 160; Reger - Rissner 1991, 239-241; Walser 2009, 146-148.

54 Ruschenbusch 1982, 182-183.

55 Ruschenbusch 1982, 182-183. For actions of Alexander, see Bonnin 2015, 270-273. 
deavour. ${ }^{56}$ Relevantly, no natural barriers separated the territories of ancient Ioulis and Koresia, ${ }^{57}$ which may have organically encouraged the exchange of population and resources between two cities; however, it had not been so for other poleis on the island, isolated due to their lands' topographies.

Should we accept the synoikism between Ioulis and Koresia in the 4th century, our perception of the island's political system must change. As it was demonstrated, the phrase

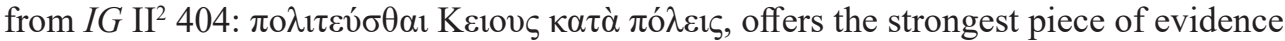
for linking the revolt with an establishment of a federal state. However, another, perhaps counterintuitive, reading of this phrase may shed more light on the discussed problemnamely, to pit it against the list of inhabitants in search of usable parallels. Crucially, the verb $\pi \mathrm{o} \lambda \iota \tau \varepsilon v ́ \sigma \theta \alpha \iota$ means not only 'to govern' but also 'to live', 'to inhabit'; 58 accordingly, the examined phrase could be read to mean that the inhabitants of the island should either manage their affairs according to their citizenship or, alternatively, simply to reside in their domestic poleis. In the latter case, the catalogue of citizens of Ioulis could refer to a group of former Koresians living in Ioulis after the latter polis incorporated Koresia, as suggested by $I G$ XII 5 609. The Athenian decree in our corpus would then refer to instances of smaller cities being absorbed into larger ones, such incorporations attested in the contemporary continental Greece (Boeotia). ${ }^{59}$ Since some citizens of smaller poleis protested against being incorporated, the resultant unrest gave other cities a perfect opportunity to meddle in affairs of their neighbours. Another practice employed by the dominant polis was to destroy the fortifications of the subordinate city; ${ }^{60}$ consequently, $I G \mathrm{II}^{2} 404$ testimony on Koresia's fortifications being rebuilt could refer to Koresia (and arguably other cities) reasserting their independence from Ioulis. ${ }^{61}$ In such a scenario, Athens would have given its support to the lesser poleis on Keos, compelling Ioulis to accept their neighbours' independence; they emphatically would not disband any federation, since none had existed at that time. ${ }^{62}$ In other words, the frequently proposed theory that Athens broke up the federal state on Keos after suppressing a revolt on the island comes from inconclusive and conflicting evidence; conversely, we can safely argue that the Athenian interference probably led to Athens supporting weaker city-states against the dominant polis on the island.

In a similar vein, let us examine the timeline of the purported federal state on Keos. The Decree of Aristoteles of 377 implies that the cities of Keos managed their affairs separately; hence, the federal state, if it existed, would either antedate or postdate 377. The analysis above demonstrated that no federation should have postdated 377 , as the

56 Reger - Rissner 1991, 236, 324.

57 Reger 1997, 451.

58 LSJ, s.v. $\pi \circ \lambda \bar{\imath} \tau \varepsilon v ́ \omega$.

59 The development of the Theban domination over other cities in Boeotia was described in detail by Bakhuizen 1994.

60 Beck 1997, 95 (Orchomenos), 99.

${ }_{61}$ Another theory proposes that that this was to defend themselves against pirate attacks. See Maier $1959,157$.

62 A similar proposal has already been put forward by Ruschenbusch (1982, 181-182), who however holds an opinion that some type of a federal state existed on Keos, to be subsequently abolished as a result of Chabrias' intervention. After the first rebellion, Ruschenbusch argues, a short-lived sympoliteia between Ioulis and Koresia emerged, to be destroyed by Athens' next move. 
text of $I G \mathrm{II}^{2} 111$ implies that the poleis of Keos evidently pursued autonomous policies in 363. In light of this, we should set 377 (the year of the oldest inscription attesting to separation of poleis on the island) as the terminus ante quem for the possible formation (and abolition) of the federal state on Keos in the 4th century. Regrettably, neither securely dated epigraphic material nor literature from the first quarter of the 4th century contain references to the federation's existence; however, an interesting piece of information surfaces in a speech of Lysias (floruit in the early 4th century), surviving in Harpocration's lexicon (ca. 2nd century CE) under the entry for the Keĩot. Lysias mentions a polis of the inhabitants of Keos in a manner indicating a political union; ${ }^{63}$ incidentally, this fragment confused the lexicographer, who felt obliged to note that the orator apparently mistook the island for a city. ${ }^{64}$ Either Lysias mispresented the island as a city (such a mistake acceptable for an orator) or Harpocration did not have knowledge to set Lysias' remark in historical context, since in Harpocration's day (ca the 2nd century CE) the island remained politically fragmented. Extrapolating from extant data on Lysias' biography, the speech in question must have been given no later than ca. $380 \cdot{ }^{65}$ if we assume that Lysias kept abreast of the political situation on Keos and his speech reflected the actual situation on the island, we could argue for a federation of poleis probably forming on Keos in the first quarter of the 4th century and lasting until 377 at the latest. The reasons why it was abolished remain unknown. The interference of the Athenians may have admittedly played a role, although Athens would have had to interfere before the cities of Keos joined the Second Athenian League. Another possible reason for disbanding the federation could be gleaned from the terms of the King's Peace (387/6), which clearly emphasised the autonomy of individual cities; ${ }^{66}$ if this was the decree that fragmented Keos, the purported federation (and Lysias' speech) would have antedated the King's Peace.

Another inscription relevant to dating the Kean federation comes from Cyrene and dates to the 330s, listing all Greek states whom the Cyrenians provided with grain supply when their own crops failed. The list includes three Kean city-states (Ioulis, Karthaia and Koresia) under double names (first the name of the island and then the specific city), as well as some unspecified Keioi ${ }^{67}$ Not grouped together, ethnicons from Keos appear randomly among inhabitants of other poleis. Scholars have produced two interpretations of this arrangement. Some believe that the ethnicon Keioi refers to the citizens of a federal state, with Cyrene providing the grain separately to every city and to the federation. ${ }^{68}$ Such a view cannot be defended after we consider the amounts given to each recipient. The Keioi, as a hypothetical federation, received 3,000 medimnoi, an amount either equal to one given to an individual city (Koresia) or even lower $(5,000$ for Ioulis and 4,000 for Karthaia). Another, more convincing interpretation identifies the unspecified Keioi as the citizens of Poiessa, the polis omitted from the roster for one reason or

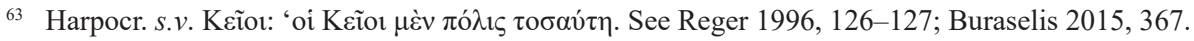

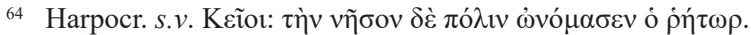

65 Turasiewicz 1999, 222-223.

66 Sinclair 1978, 29-31.

67 SEG 9.2 = Rhodes - Osborne 2003, no. 96, ll. 46, 51, 53, 55.

68 Brun 1989, 137-138. 
another. ${ }^{69}$ Significantly to this analysis, the famine relief inscription from Cyrene depicts the political makeup of Keos in a post-revolt period, after the Second Athenian Confederation dissolved and Keos won its freedom from Athens. Should we follow the second interpretation of the Cyrenian inscription and assume that the Kean poleis did not form a federation in the 330s, then we must assume that local polities remained unwilling to unite with their neighbours even without the Athenian interloping. Relevantly to the context of the 330s, Lycurgus names the inhabitants of Keos as those who remained loyal to Athens after its defeat at Chaeronea. ${ }^{70}$

The mass of evidence surveyed above indicates that separatist and unionist tendencies coexisted in an uneasy balance on Keos. It is likely that, at one point (in the late the 5 th or early 4th century), select Kean poleis formed a political body that covered only a part of the island's territory and had the support of a minority of citizens. Since very few documents testify to its existence, the union must not have lasted long, breaking up at some point in the first quarter of the 4th century. Later, in the Hellenistic period, the Kean federation reunified for a little while, ${ }^{71}$ but soon parted ways again, ${ }^{72}$ pointing to decentralising tendencies among the islanders. Both the Kean unwillingness to federate and the Athenian meddling may have caused the collapse of the federal state: the Kean union apparently had detractors within and abroad.

Ioulis, the largest, centrally located polis on Keos, particularly promoted federationism at expense of its neighbouring poleis ${ }^{73}$ the numismatic material and extant inscriptions reveal that the city dared to confront both Athens and other Kean city-states. Markedly, Ioulis does not appear on the list of Kean cities that had their fortifications rebuilt ( $\left.I G \mathrm{II}^{2} 404\right)$, which could mean that it dominated other city-states, since its walls were never destroyed as a show of dominance by another polis. The other poleis hesitated to federate and preferred to placate rather than antagonise Athens. In our sources, only Ioulis and Karthaia were said to have rebelled during the first revolt, whereas other leading Kean cities, Poiessa and Koresia, chose not to challenge the Athenian supremacy. In contrast to Ioulis, Karthaia (the second largest city) apparently adopted a conciliatory attitude towards Athens: markedly, Ioulis started the second revolt on its own. According to L. Mendoni's convincing interpretation, a dedication (mentioning the Athenian culture hero Theseus) on the temple of Apollo in Karthai (dated by him to the 4th century) might be a manifestation of the pro-Athenian mood in the city. ${ }^{74}$ Although promising, this interpretation remains tentative, since Mendoni's uncertain dating of the dedication builds solely on her analysis of shapes of letters in the dedication's individual words. More relevantly, Aristophon, the statesman who suggested the solution described in $I G \mathrm{II}^{2} 111$, is believed to have been a proxenos of the poleis of Karthaia, pointing to this city favouring Athenians in the brewing conflict ${ }^{75}$

\footnotetext{
69. Ruschenbusch 1982, 183-184; Buraselis 2015, 369.

7 Lyc. Leocr. 42.

71 Reger - Rissner 1991, 239-240.

72 Reger - Rissner 1991, 239-241.

73 Pridik 1892, 6-7.

74 Mendoni 1990, 288-292.

75 IG XII 5.542, l. 43.
} 
In the light of the entire body of the evidence presented above, a considerable percentage of the Kean islanders appear to have been sceptical about benefits of belonging to a united political community. For the smaller cities, joining a federation often meant being dependent on their larger neighbours, a tendency possibly exemplified by the alleged annexation of Koresia by Ioulis. Perhaps lesser poleis preferred to depend on remote Athenian overlords rather than on their capricious, stronger neighbours. What is certain, however, is that all local tension on Keos created excellent opportunities for neighbouring states to interfere in the Kean affairs. After the King's Peace was signed, the resultant turmoil encouraged many stronger powers to impose their will on their smaller neighbours. For example, Sparta took advantage of tensions on the Chalcidice peninsula to make an armed intervention and forcibly dissolve the Olynthos-led Chalcidian League. Sparta also capitalised on internal dissent in Thebes to capture the city, actively aided by some of its inhabitants. ${ }^{76}$ The situation of the Aegean island of Keos would therefore closely resemble the situation in continental Greece.

The Kean history reveals a great deal about the Athenians' attitudes towards their allies in the Second Athenian League. Although no evidence exists that Athens dissolved any putative federal state on Keos, one cannot deny that they exerted their influence on the Kean cities. The Athenian dominance appears clearly in inscriptions recording the conciliatory post-rebellion accords on the island, especially in the decision to move court proceedings off the island to the Athens. We should remember, however, that Athens imposing its will on Keos happened in response to the earlier riots on the island. ${ }^{77}$ Other fragmentary sources provide further pieces of evidence concerning the Athenian sway over the island. First, we know of Athens restricting the Kean trade in a locallymined material called miltos (most likely a type of ochre), ${ }^{78}$ with a surviving inscription specifying restrictions on Keos selling the material to external polities. Unfortunately, the inscription (and therefore its political context) cannot be precisely dated, although historians commonly point to the mid-4th century ${ }^{79}$ Second, it is possible that some Athenians have used their status to exploit the Keans in certain manner. A passage from Hypereides' speech against Aristophon intimates that Aristophon went on trial for failing to properly settle the affairs on Keos, with Hypereides accusing him of taking advantage of the Keans out of greed. What exactly Aristophon may or may not have done remains unsaid; in the light of the Athenians' relative leniency in response to the Kean riots, he can hardly be accused of terrorising the islanders. ${ }^{80}$ Perhaps Hypereides denigrated Aristophon for political gain, using unfounded accusations to incite the crowds; yet, Hypereides' rhetorical choices signify that at least some accusations could have affected or hurt some listeners in the intended way, with the Athenians conceivably being guilty of asserting their supremacy in a manner some Keans could have found offensive. Regardless, as I have demonstrated, we should not overemphasise the scale of the Athenian interference in the internal affairs on Keos, since, as it is evident, the Athenian actions may have been supported by a considerable percentage of the islanders. Although we can

76 Sinclair 1978, 37.

77 Sealey 1957, 108: 'Special circumstances justified the few clear breaches of its rules.'

$78 I G \mathrm{II}^{2} 1128$ = Rhodes - Osborne 2003, no. 40. For the material, see Photos-Jones 1997, 359-372.

79 Hyper., Frgs. 40-44.

80 Cooper 2008, 46. 
hardly assume that Athens completely abandoned its imperialistic aspirations towards the members of the Second Athenian League, the dominant city-state certainly made an effort not to alienate one's subordinates just for the sake of asserting dominance.

\section{BIBLIOGRAPHY}

Accame, S. (1941), La Lega Ateniese del secolo IV a. C., Roma.

Badian, E. (1995), The Ghost of Empire. Reflections on Athenian Foreign Policy in the Fourth Century BC, in: W. Eder (ed.) Die athenische Demokratie im 4. Jahrhundert v. Chr., Stuttgart: 79-106.

Bakhuizen, P. C. (1994), Thebes and Boeotia in the Fourth Century B.C., Phoenix 48: 307-330.

Beck, H. (1997), Polis und Koinon, Untersuchungen zur Geschichte und Struktur der Griechischen Bundesstaaten im 4. Jahrhundert v. Chr., Stuttgart.

Beloch, K. J. (1922), Griechische Geschichte, Bd. III, Berlin-Leipzig.

Bonnin, G. (2015), De Naxos à Amorgos. L'impérialisme athénien vu des Cyclades à l'époque classique, Bordeaux.

Brun, P. (1989), L'île de Kéos et ses cités au IVe siècle av J.-C., ZPE 76: 121-138.

Brun, P. (2004): La datation de „IG” II ${ }^{2} 404$, décret athénien concernant les cités de Kéos, ZPE 147: 72-78.

Buckler, J. (2003), Aegean Greece in the Fourth Century B.C., Leiden-Boston.

Buraselis, K. (2015), Federalism and the Sea: The koina of the Aegean Islands, in: H. Beck, P. Funke (eds.), Federalism in Greek Antiquity, Cambridge: 358-376.

Bürchner, L. (1921), Keos, RE IX, 181-190.

Cargill, J. (1981), The Second Athenian League, Berkeley.

Cawkwell, G. L. (1981), Notes on the Failure of the Second Athenian Confederacy, JHS 101: 40-55.

Cloche, P. (1934), La politique étrangère d'Athènes de 404 à 338 avant Jésus-Christ, Paris.

Cooper, C. (2008), Hypereides, Aristophon, and the Settlement of Keos, in: C. Cooper (ed.), Epigraphy and Greek Historian, Toronto: 31-56.

Davies, J. K. (1969), The Date of the IG II² 1609, Historia 18: 303-333.

Dreher, M. (1989), Zu IG II ${ }^{2}$ 404, Dem athenischen Volkbeschluss über die Eigenstaatlichkeit der keischen Poleis, in: G. Thür (ed.), Symposion 1985. Vorträge zur Griechischen und hellenistischen Rechtsgeschichte, Köln-Wien: 263-281.

Gehrke, H. J., Wierbelauer, G. (2004), Kranioi, Paleis, Pronnoi, Same, in: M. H. Hansen, T. H. Nielsen (eds.), An Inventory of Archaic and Classical Poleis, Oxford: 364, 369-371.

Hornblower, S. (1982), rev. of Cargill 1981, CR 23: 235-239.

Laqueur, W. (1927), Epigraphische Untersuchungen zu den griechischen Volksbeschlüssen, Leipzig.

Lewis, D. M. (1962), The Federal Constitution of Keos, BSA 57: 1-4.

Maier, F. G. (1959), Griechische Mauerbauinschriften, Bd. I, Heidelberg.

Marshall, F. H. (1905), The Second Athenian Confederacy, Cambridge.

Martin, T. (1984), rev. of Cargill 1981, CP 79: 243-247.

Mendoni, L. (1990), Addenda et Corridenda ad Inscriptiones Ceae, MELETHMATA 10: 287-307.

Meritt, B. D., Wade-Gery, H. T., MacGregor, M. F. (1950), The Athenian Tribute Lists, vol. III, Cambridge-Princeton, New Jersey.

Perlman, S. (1968), Athenian Democracy and the Revival of the Imperialistic Expansion at the Beginning of the 4th Century B.C., CPh 63: 257-267.

Photos-Jones, E. (1997), Kean Miltos: The Well-Known Iron Oxides of Antiquity, BSA 92: 359-372.

Pridik, A. (1892), De Cei Insulae Rebus, Berlin. 
Reger, G. (1996), Islands with One Polis versus Islands with Several Poleis, in: M. H. Hansen (ed.), The Polis as an Urban Centre and as a Political Community, Copenhagen: 450-492.

Reger, G. (1998), Polis Denoting a Large Geographical or Political Unit, in: M. H. Jansen (ed.), Polis and City-State An Ancient Concept and Its Modern Equivalent, Copenhagen: 124-132.

Reger, G. (2004), The Aegean, in: M. H. Hansen, T. H. Nielsen (eds.), An Inventory of Archaic and Classical Poleis, Oxford: 732-793.

Reger, G., Rissner, M. (1991), Coinage and Federation in Hellenistic Keos, in: J. F. Cherry, J. L. Davis, E. Mantzourani (eds.), Landscape Archaeology as Long Term History, Los Angeles: 305-314.

Rhodes, P. J. (2012), The Alleged Failure of Athens in the Fourth Century, Electrum 19: 111-129.

Rhodes, P. J., Osborne, R. (2003), Greek Historical Inscriptions 404-323 BC, Oxford.

Robert, L. (1960), Sur un décret des Korisiens au Musée de Smyrne, in: L. Robert (ed.), Hellenica, vol. 11-12, Paris: 132-176.

Ruschenbusch, E. (1982), IG XII 5, 609: Eine Bürgerliste von Iulis und Koresia auf Keos, ZPE 48: $175-188$.

Ruzicka, S. (1998), Epaminondas and the Genesis of the Social War, CP 93: 60-69.

Schweigert, E. (1939), Greek Inscriptions, Hesperia 8: 1-47.

Sealey, R. (1957), IG II 1609 and the Transformation of the Second Athenian Sea-League, Phoenix 11: $95-111$

Sinclair, R. (1978), King's Peace and the Employment of Military and Naval Forces 387-378, Chiron 8: $29-54$.

Stylianou, P. J. (1998), A Historical Commentary on Diodorus Siculus Book 15, Oxford.

Swoboda, H. (1923), Zwei Kapitel aus dem Griechischen Bundesrecht, Wien.

Thomopoulos, J. (1954), Inscriptions de Céos, BCH 78: 316-348.

Turasiewicz, R. (1999), Życie i twórczość Lizjasza, Warszawa.

Walser, A. V. (2009), Sympolitien und Siedlungsentwicklung, in: A. Matthaei, M. Zimmerman (eds.), Stadtbilder in Hellenismus, Berlin: 135-155. 